\title{
Falar bonito: \\ o Kitsch como estratégia discursiva
}

O discurso é o meio por excelência da ação política ${ }^{1}$. É ele que estabelece as relações entre líderes e liderados; é o acesso ao discurso, a capacidade de falar em nome de outros, que torna alguém representante - ou seja, porta-voz - de um grupo.

Esta mediação, porém, não é isenta de problemas. Há, é claro, o fato de que, como em todas as outras formas de comunicação discursiva, a linguagem intervém e tanto permite a expressão como a circunscreve e limita - uma vez que, segundo observou André Gorz, ecoando aqui temas presentes em Rousseau, ela "é um filtro que me obriga sempre a dizer mais e menos do que aquilo que sinto” (Gorz, 1988, p. 216). Mas há também o fato de que, na comunicação política, emissores e receptores se encontram na situação de uma brutal assimetria.

Em virtude da divisão social do trabalho político, os representantes devem submeter ao público assuntos com os quais ele está, via de regra, precariamente familiarizado. Nas democracias representativas, em especial, os cidadãos comuns são tanto afastados da gestão das questões públicas quanto chamados a decidir sobre elas de tempos em tempos. Os

\footnotetext{
Da concepção inicial à forma definitiva, este artigo se beneficiou das observações de Regina Dalcastagnè. Flávia Biroli leu e comentou uma versão anterior. Outra versão foi apresentada no Grupo de Trabalho "Comunicação e política", do XV Encontro Naacional da COMPÓS (Bauru, 2005), beneficiando-se das críticas de Alessandra Aldé, Fernando Lattman-Weltman, Milena Weber, Wilson Gomes e outros participantes. A todos agradeço, permanecendo, é claro, como único responsável pelas falhas e omissões.
} 
problemas da comunicação política tendem, assim, a ser encarados como problemas de tradução: como transmitir ao público, que é leigo, posições sobre temas complexos.

Mas nem sempre a tradução é o objetivo dos agentes políticos. Pierre Bourdieu observa que "os discursos não são apenas (a não ser excepcionalmente) signos destinados a serem compreendidos, decifrados; são também signos de riqueza a serem avaliados, apreciados, e signos de autoridade a serem acreditados e obedecidos" (Bourdieu, 1998a [1982], p. 53). O discurso político é uma ilustração singular desta observação geral.

A compreensão truncada ou limitada da fala do político pode ser não um empecilho a ser contornado, mas algo que se busca deliberadamente. Produzir um discurso que o público não compreende por inteiro pode significar uma marca de distinção - a distinção entre aqueles capazes de fazer política e os outros, que não podem ser mais que espectadores. Essa distinção está na base do sistema representativo e é fundamental para resolver a contradição entre o caráter formalmente democrático do sistema e seu funcionamento que é, no final das contas, censitário (Bourdieu, 1979, p. 464).

O discurso político, assim, não é transparente e também não deseja sê-lo. As motivações dos agentes são travestidas em ideais mais elevados - em vez da obtenção do poder, buscar-se-ia alguma espécie de "bem comum"2. É um deslocamento mais do que frequente no discurso político; na verdade, é um fenômeno banal e os exemplos poderiam ser multiplicados com facilidade. Mas não se trata apenas da hipocrisia, que La Rochefoucauld já definia como sendo "a homenagem que o vício presta à virtude". A transposição de interesses imediatos em ideais elevados é própria da representação política (ou, mais propriamente, da representação estruturada em carreiras políticas), em que a promoção de um projeto ou de um ideário político parece estreitamente vinculada ao sucesso dos indivíduos que os encarnam.

Não são apenas os ideais que parecem elevados, mas também os termos que os definem. O discurso político traveste disputas prosaicas em questões de princípios, ao mesmo tempo em que traveste a si próprio num discurso mais sofisticado do que de fato é. Esta característica, que não parece ser

\footnotetext{
Um exemplo claro é o da aprovação da emenda da reeleição, no Brasil, durante o primeiro mandato presidencial de Fernando Henrique Cardoso. A linha divisória entre defensores e opositores da medida era aquela que separava quem se beneficiaria e quem seria prejudicado com ela. Mas a discussão se fez em termos da "ampliação da accountability" contra as "tradições republicanas". Estavam em jogo, aparentemente, não ambições e carreiras, mas valores políticos essenciais.
} 
fortuita ou contingente, serve aqui como ponto de partida para a discussão de uma categoria analítica que chamo de "Kitsch político".

A primeira seção do artigo discute tentativas de construção de um conceito de Kitsch político, apresentando críticas a elas e indicações de um rumo alternativo, a partir de um paralelismo com determinadas compreensões sobre o Kitsch estético. A segunda seção discute as implicações destas características do discurso político para o funcionamento dos sistemas representativos. Por fim, as conclusões problematizam o uso da categoria, apontando seu potencial, mas também suas limitações.

\section{Um rótulo em busca de um conceito}

O que pode significar o Kitsch político? Não se trata de uma expressão muito difundida. Em maio de 2011, uma pesquisa no Google indicou apenas 3.890 páginas contendo a expressão "political Kitsch", contra - por exemplo - mais de 19 mil para "political imaginary", mais de 84 mil para "political myth", quase 800 mil para "political speech" e mais de 1,5 milhão para "political discourse", além, é claro, de cerca de 290 milhões para "Lady Gaga"3. Em geral, no uso comum, o Kitsch político se refere aos símbolos visuais das campanhas eleitorais, a cartazes e bandeirolas de duvidoso gosto estético afixados pelos partidos e candidatos.

Entre as noções mais elaboradas do Kitsch político, a mais difundida foi criada pelo romancista tcheco Milan Kundera, em seu best-seller da guerra fria, $A$ insustentável leveza do ser. Refere-se à criação de um espaço imaginário em que crenças e certezas são mantidas a salvo do contágio por uma realidade que nem sempre (ou quase nunca) se adequa a elas. Como categoria geral, o Kitsch "é a negação absoluta da merda, no sentido literal como no figurado: o Kitsch exclui de seu campo de visão tudo o que a existência humana possui de essencialmente inaceitável” (Kundera, 1984 [1983], p. 357). Tal como qualquer outra forma de Kitsch, o Kitsch político zelaria pela permanência de valores puros, intocados, em que o bom e o belo reinariam sem mácula. As mitografias dos regimes totalitários são os exemplos preferidos pelo autor, mas também é possível encontrá-los nas democracias - basta pensar no culto dos founding fathers estadunidenses. As narrativas patrióticas e,

Em outras línguas, a coleta foi igualmente minguada:"Kitsch político/politico", recuperando a expressão em português, espanhol e italiano, acusou 14.700 páginas; "Kitsch politique", em francês, não passou de 389; e "politischer Kitsch", em alemão, apenas 223. 
de modo geral, a memória oficial dos Estados nacionais, qualquer que seja a ideologia que professam, seriam o habitat natural do Kitsch político, na acepção de Kundera.

Um esforço mais acadêmico de construção de um conceito de Kitsch político, por derivação do Kitsch estético, foi efetuado recentemente pelo cientista político argentino Martín Plot. Seguindo a maior parte dos autores que se debruçaram sobre o assunto, ele toma, como atributo central do Kitsch artístico, a imposição de efeitos predeterminados sobre seu público, em contraposição à arte "autêntica", caracterizada pela abertura e indeterminação. A analogia com a política torna-se bastante evidente, uma vez que o autor trabalha com um referencial arendtiano, vendo na indeterminação do resultado a quintessência da política - ou, ao menos, da "boa política" ou da "verdadeira política". O resultado é, assim, uma denúncia bastante convencional da pasteurização do discurso político, que se resume a reproduzir aquilo que as sondagens de opinião e os focus groups indicam, negando as características criadoras da política.

O Kitsch político, assim, "tende a reduzir a um mínimo a criatividade implícita em toda política democrática, limitando-se à manifestação de posições públicas que cumpram a condição de ter sido suficientemente testadas sobre sua aceitação pública potencial" (Plot, 2003, p. 15). Desdobramento e radicalização de um elemento sempre presente na lógica política, que é a busca do apoio do público, seu triunfo implica o esvaziamento de um modo alternativo do fazer político, que Plot chama de "política ideológica" e que consiste na manutenção coerente de princípios, ainda que possam parecer impopulares, e na ação/discurso inovadora. As razões do triunfo da "má" política sobre a "boa" apontam para os suspeitos de sempre, isto é, os meios de comunicação de massa.

As insuficiências desta abordagem principiam pela própria dicotomia que separa as "verdadeiras" obras de arte de suas falsificações, com base na abertura ou pré-determinação de efeitos, presente no conceito do Kitsch estético. Em sua influente definição da "obra aberta", Umberto Eco ressalta a participação ativa do leitor, ouvinte ou espectador; "cada fruição é, assim, uma interpretação e uma execução, pois em cada fruição a obra revive dentro de uma perspectiva original" (Eco, 1988a [1962], p. 40). Mas, a rigor, esta característica não é distintiva. Todo conteúdo simbólico, incluídos aí tanto obras artísticas quanto discursos políticos, pode sofrer diferentes apropria- 
ções por parte de seus receptores. A maior indeterminação atribuída às obras consideradas superiores não vem, possivelmente, de características intrínsecas, mas da sedimentação de um conjunto de interpretações legitimadas por uma tradição crítica. O próprio Eco, voltando ao tema, observa que "a 'estrutura de uma obra aberta' não será a estrutura isolada das várias obras, mas o modelo geral (...) que descreve não apenas um grupo de obras, mas um grupo de obras enquanto postas numa determinada relação fruitiva com seus receptores" (Eco, 1988b [1967], p. 29; ênfase suprimida). Sobretudo ao indicar que as obras são postas em certa relação com seus receptores, $o$ trecho permite superar o que Bourdieu (1979) chama de "ideologia carismática" da criação e do consumo estéticos, entendendo que os atributos de "artisticidade" são produtos sociais.

A transposição do critério para o campo político é ainda mais problemática. Mesmo em se tratando da criação artística, é questionável a crença de que algum autor se abstenha por inteiro de buscar produzir determinados efeitos sobre seu público. Para a política, então, em que a disputa pelo poder nunca está ausente, tal crença é insustentável. Como observou Habermas, ao criticar a concepção de política de Hannah Arendt por não conceder espaço à competição estratégica: "A política não pode ser idêntica, como supõe $H$. Arendt, à práxis daqueles que conversam entre si, a fim de agirem em comum" (Habermas, 1980 [1976], p. 115). O discurso político nunca deixa de ser um discurso interessado (e, assim, ao menos em potencial, conflituoso); tentar retirar tal característica em nome de uma percepção normativa de qual a maneira "certa" de se portar na esfera pública significa se colocar numa posição que inviabiliza a compreensão de qualquer fenômeno político real.

Assim, minha tentativa de construção de uma categoria de Kitsch político segue em direção oposta à de Plot, sugerida, de maneira mais do que sumária, em texto anterior (Miguel, 2002a, p. 178). Não há o compromisso normativo com o ideal de uma "boa política", a ser resgatada das influências negativas que a desvirtuam nas sociedades contemporâneas. O que se procura é entender uma das condições de eficácia do discurso político, que passa exatamente pelo descumprimento de preceitos de eficácia que, em geral, regem este mesmo discurso político. Como pretendo demonstrar na seção seguinte, o paradoxo está ligado ao estatuto ambíguo da representação política democrática; e a discussão serve para problematizar alguns aspectos da utopia deliberacio- 
nista, de inspiração habermasiana, que hoje assume a posição de principal farol teórico para quem deseja melhorar a qualidade das democracias.

Para tanto, escolho como ponto de partida outra característica definidora do Kitsch artístico, em vez da imposição de efeitos pré-fabricados sobre seus consumidores, como fez Plot. É a aspiração do Kitsch à artisticidade. Enquanto o brega se expõe na sua nudez de artefato comercial - e o naïf, ao contrário, encontra em sua própria despretensão um meio de ascender à condição de realização estética -, o Kitsch incorpora signos que são socialmente reconhecidos como pertencentes à "verdadeira arte", tentando legitimar-se através deles. Este é o ponto central (e ao qual retornarei) na transposição do conceito para o campo da prática política.

$\mathrm{Na}$ era da comunicação de massa, o discurso político precisou se adaptar às formas e fórmulas dos novos veículos, bem como às suas rotinas produtivas. Conforme uma vasta literatura não se cansa de apontar, o político midiático é aquele que entende que seu público foi educado pela linguagem dos meios eletrônicos, sobretudo a televisão, e assim se adapta a este ambiente. Ele possui uma preocupação redobrada com sua imagem visual, entendida como um poderoso transmissor dos atributos simbólicos que deseja possuir, uma vez que, no público, a visão é o sentido dominante e se sobrepõe até à reflexão racional. Ele evita pronunciamentos longos e raciocínios aprofundados, uma vez que a prática do telejornalismo é a reportagem curta, com sound-bites de duração reduzida, e a programação de entretenimento também privilegia uma edição movimentada, para não dizer frenética. Ele sabe, sobretudo, que o discurso político é um "estranho no ninho" dos meios eletrônicos e procura apagar ao máximo os signos de dissimilitude, mimetizando o feitio narrativo predominante na programação, a edição picotada, o tom leve ou os formatos da publicidade comercial.

Ainda que excessivamente unilateral, este entendimento das transformações do discurso político na era da televisão está, em linhas gerais, correto. Menos aceitável é o subtexto, quase sempre implícito, de que os meios eletrônicos "deturparam" a comunicação política, que antes se desenrolaria em nível muito mais elevado. Christopher Lasch pode suspirar pelos debates Lincoln-Douglas, que combinavam "análise exaustiva de questões complexas", "sinceridade" e "posições claras" (Lasch, 1995 [1995], p. 192). Mas os políticos do século XIX também precisavam dominar um conjunto de ferramentas retóricas para atingir de maneira mais eficaz suas platéias. 
Lincoln e Douglas não encenaram sete debates em diferentes cidades, na campanha ao senado por Illinois em 1858, como um enfrentamento puro de ideias. Eles cuidavam de suas personas públicas e treinavam suas técnicas de persuasão, tal como fazem os políticos de hoje. Dominavam as armas da retórica, calibravam a entonação de voz, conheciam o repertório mental de seu público e sabiam quais valores o sensibilizavam.

Hoje, é claro, conhecer as regras da retórica tradicional não é forçosamente o melhor bilhete de ingresso para o centro da arena política. As habilidades necessárias para o sucesso na luta política mudaram porque mudou o ambiente em que tal luta se dá. O extraordinário desenvolvimento dos meios de comunicação de massa é um elemento fundamental desta transformação, mas não é o único. Também é relevante a democratização do processo político, no sentido de que mais pessoas são chamadas a participar, ao menos no momento eleitoral, e manifestam menos deferência aos seus superiores sociais. Ou seja, o político fala num ambiente diferente, moldado pela mídia, mas fala também para um público diferente. Não por acaso, a crítica conservadora que lamenta o declínio na qualidade dos governantes apresenta outro vilão, além da emergência dos meios eletrônicos de comunicação: o sufrágio universal (para uma ampla resenha, ver Losurdo, 2004 [1993]).

O que se está dizendo aqui não deve obscurecer o fato de que o discurso político na mídia não mimetizou integralmente o formato predominante da programação. Na medida em que reconhece este fenômeno, a literatura predominante tende a percebê-lo como a manifestação "residual" de uma lógica política que ainda não conseguiu se amoldar plenamente às exigências do novo ambiente em que se processa:

Tudo aquilo que na telepropaganda parece não se adaptar, ou se adapta mal, à lógica dos meios deve ser, de preferência, excluído ou reduzido ao mínimo, se excluído não puder ser. Este resíduo (os discursos longos, com raciocínios sutis ou sofisticados, ou que exijam grande competência cultural do espectador, por exemplo) é o inevitável aspecto tedioso e frio da telepropaganda, extemporâneo da lógica do entretenimento ou, para usar o termo característico desta época de velocidade e leveza, é o aspecto chato da propaganda política (Gomes, 2004, p. 206; ênfase suprimida).

Apresento aqui uma perspectiva divergente. $\mathrm{O}$ ajuste imperfeito entre $\mathrm{o}$ discurso político e a lógica da mídia de massa não deve ser entendido como 
um sintoma de incapacidade de fazer melhor, mas como uma condição mesma da eficácia política daquele discurso. O objetivo do político não é entreter sua audiência, mas transformá-la em apoio - crucialmente, nos períodos eleitorais, em votos. É necessário entretê-la, já que sem cativar de alguma maneira sua atenção não será possível arrebanhá-la, mas este é um meio, não um fim em si mesmo.

Assim, o paralelo mais adequado não é do discurso político midiatizado com a programação corrente, de entretenimento ou mesmo jornalística, mas com a publicidade comercial. A publicidade comercial não visa entreter, mas vender; neste sentido, um mau anúncio (do ponto de vista da criatividade, da técnica ou da fruição estética que provoca no público) pode ser melhor do que um "excelente" anúncio, ganhador de leões de ouro em Cannes, desde que proporcione a venda de mais produtos ou contribua mais para a fixação de uma marca. Da mesma forma, a meta do político é a ampliação de sua base de apoio. O folclórico José Maria Eymael pôde afirmar que sua candidatura à presidência da República, em 1998, teve como principal fruto tornar seu jingle conhecido em todo o Brasil ("ey, ey, Eymael, um democrata cristão...”), mas tal excentricidade apenas confirma a adequação do adjetivo "folclórico" aplicado a ele ${ }^{4}$.

Na busca da adesão de sua assistência, o político deve marcar a si mesmo com os sinais das qualidades que o tornam merecedor do apoio popular. Por vezes, tais sinais podem ser indicados pela adoção de um formato de discurso que se choca com o corrente. O "falar bonito" - que implica em usar palavras difíceis, construções mais elaboradas, termos técnicos, enfim, empecilhos à comunicação fluida com o receptor - é percebido como indício de educação, de cultura e de familiaridade com problemas que, para outros, são arcanos. Incapaz de deglutir o conteúdo da fala, o receptor é perfeitamente competente, por outro lado, para decifrar os signos de distinção embutidos em sua forma.

Há que acrescentar, ainda, que - por mais que tantos comentaristas afirmem que a política é hoje um ramo do show-business - o cidadão comum não espera nem deseja que seu líder seja um entertainer. Se a política perdeu relevância nas sociedades contemporâneas, em que as decisões fundamentais

Ainda hoje, o perfil de Eymael no seu site de campanha e no site de seu partido destaca o fato de que o jingle é "nacionalmente conhecido". Ver www.vote27eymael.blogspot.com e www.psdc.org.br/ presidente (acessos em abril de 2011). 
são cada vez mais tomadas à margem da esfera do poder público, ainda faz parte do jogo aceitá-lo como da maior seriedade e importância. O homem ou a mulher que desejam fazer parte dele podem precisar dos talentos de um comunicador, mas não convém aparentá-los. O público quer "estadistas", não apresentadores de programas de auditório. O excesso de mimetismo da linguagem midiática pode ser, assim, contraproducente.

O discurso político, portanto, precisa buscar um delicado equilíbrio entre as estratégias de simplificação e aproximação com seu público, necessárias para estabelecer a comunicação, e as pitadas de distinção, que marcam a superioridade social daquele que o enuncia, credenciando-o com os atributos de seriedade, preparo e competência que este mesmo público julga necessários para o exercício das funções públicas. Não há um ponto correto, determinado de antemão, já que a estratégia discursiva mais adequada é determinada pelas características do público, pelo momento político e, em especial, pelas características da persona que o político deseja projetar. Dito de outra forma, o que vale para um político não vale para o outro; o que funciona em determinadas circunstâncias fracassa em outras.

É essa oscilação entre o produto de consumo fácil e a obra de qualidade elevada que pretendo apontar como característica definidora do Kitsch estético, aplicável também ao campo político. Sem descartar outros elementos do conceito, como a imposição de efeitos pré-fabricados, Umberto Eco ressalta, no Kitsch, o fato de se constituir em "meio de afirmação cultural fácil, por um público que se ilude, julgando consumir uma representação original do mundo enquanto, na verdade, goza apenas de uma imitação secundária da força primária das imagens" (Eco, 1993 [1964], p. 69). O Kitsch, prossegue o semiólogo italiano, "tende continuamente a sugerir a idéia de que, gozando destes efeitos [fáceis], o leitor esteja aprimorando uma experiência estética privilegiada" (Eco, 1993 [1964], p. 71; ênfase suprimida).

O Kitsch político, portanto, remete às estratégias discursivas de distinção, que propiciam ao cidadão a sensação de acompanhar a "alta política" - associada à "disputa de ideias", à discussão aprofundada, ao confronto entre projetos, a perspectivas de longo prazo - quando, de fato, o que tem diante de si é apenas a política tout court, isto é, homens e (algumas) mulheres lutando por posições de poder. Acompanhando (pretensamente) a "alta política”, o cidadão comum se sente elevado, mas também excluído, já que é uma esfera que estaria além de sua participação ou mesmo compreensão. 
Convém ressaltar que a correta apreensão por parte do público não é uma condição necessária para a eficácia do discurso político. Ao relatar curiosas confusões por parte dos trabalhadores ingleses radicais do início do século XIX, que, por exemplo, entendiam a palavra-de-ordem "sufrágio universal" como sendo sinônimo de um solidário "sofrimento universal" (se um sofre, todos sofrem junto), E. P. Thompson anota que "idéias e termos" podem ter "um valor mais fetichista do que racional" para os militantes (Thompson, 1987 [1963], vol. III, p. 305). Aqui, na verdade, estou postulando algo menos: não a adesão irracional a um slogan enigmático, mas a permeabilidade aos supostos signos de uma competência que não se sabe avaliar.

Se o Kitsch artístico é "o estilema separado do próprio contexto, inserido em outro cuja estrutura geral não possui as mesmas características de homogeneidade e necessidade da estrutura original" (Eco, 1993 [1964], p. 110; ênfase suprimida), o Kitsch político é o fragmento do discurso elaborado, profundo, deslocado de sua origem, transformado em ornamento de outro discurso. Tornado, a rigor, um significante que apenas falsamente remete a um significado original, já que seu sentido é apenas denotar as qualidades superiores daquele que o emite.

\section{Kitsch e representação política}

A eficácia - dir-se-ia quase a necessidade - do emprego do Kitsch no discurso político está associada às peculiaridades de um regime político que se quer tanto democrático quanto representativo. Nas sociedades contemporâneas de tipo ocidental, a soberania pertence nominalmente ao povo, mas o poder é exercido por um pequeno grupo de pessoas. A relação entre o povo, titular do poder, e aqueles que o exercem em seu nome é tênue. A intervalos regulares, o povo é chamado a autorizar os governantes, por meio do processo eleitoral. Uma vez autorizado, o representante não possui qualquer compromisso formal de respeitar as vontades de seus constituintes. Apenas sabe que, se quiser renovar seu mandato, precisará do apoio dos eleitores na próxima disputa.

O espaço da representação na política não se reduz, é claro, à autorização eleitoral. Ainda que na ausência de mandatos formalmente concedidos, os líderes políticos representam determinados grupos sociais, definidos por classe, profissão, moradia, opinião ou outro critério, atuando como seus porta-vozes na esfera pública. A representação política, portanto, não se 
vincula necessariamente à democracia política. Em sociedades tradicionais, os superiores hierárquicos aparecem como representantes de seus subordinados, da mesma forma como se diz que um monarca representa o conjunto da nação. Neste sentido, a representação política está vinculada à capacidade de falar em lugar de outro, o que vai levar um de seus mais importantes teóricos a observar que é a presença de um representante que gera um grupo social, pois o grupo não existe enquanto tal se não tem uma voz na qual se reconhecer e constituir sua unidade (Hobbes, 1980 [1651], p. 135) 5 .

A democracia, por sua vez, nasce dissociada da representação. Não que a representação política estivesse ausente da Atenas antiga, de onde tiramos a palavra e, mais importante, uma parcela significativa do imaginário associado à democracia. No sentido de falar em lugar de alguém, a representação sempre esteve presente, uma vez que nem todos os cidadãos participavam das assembleias populares e, entre os que estavam presentes, poucos tomavam a palavra. Muitos cidadãos, portanto, se julgavam representados nas falas de outros (Finley, 1988 [1973]). Isto não quer dizer que não houvesse uma diferença radical entre o modelo ateniense e os regimes democráticos contemporâneos. Em Atenas, para aqueles que tinham acesso à cidadania, ser representado era uma opção. Sempre havia a possibilidade de se fazer ouvir no espaço de tomada de decisões, pois um dos elementos centrais da democracia antiga era a isegoria, isto é, o direito igual à fala na ágora.

Se, entendida em sentido lato, a representação era um componente da política ateniense, como o é de qualquer organização política, por outro lado o pensamento antigo excluía da democracia o mecanismo da eleição, que hoje encaramos como a forma principal de escolha de representantes. Até, pelo menos, o século XVIII, a eleição era vista como um mecanismo tipicamente aristocrático, voltado a selecionar "os melhores". Um regime democrático fundava-se na crença da igualdade entre todos os cidadãos; nada mais natural, portanto, que sua forma característica de preenchimento de cargos públicos fosse o sorteio.

Em seu estudo sobre as origens dos governos representativos contemporâneos, a partir das revoluções inglesa, americana e francesa, Bernard Manin observa que nossas "democracias representativas" não nascem como

Em sua teoria da representação, Hobbes está preocupado em negar a possibilidade - indicada por autores protodemocráticos, como Althusius (2003 [1614], p. 252) - de existência de um povo sem príncipe. Sem a autoridade, não há um povo, apenas uma multidão atomizada. 
uma evolução ou adaptação dos ideais antigos de soberania popular a novas condições sociais (Estados extensos e populosos, maior complexidade dos negócios públicos), mas como fruto de uma busca deliberada pela contenção do elemento democrático. Tratava-se de garantir o monopólio do governo por parte de indivíduos seletos, cujo discernimento, inteligência e virtude cívica - além da posição na hieraquia social e da riqueza - seriam superiores aos da massa da população.

"O fato fundamental sobre as eleições", diz Manin, “é que elas são simultânea e indissoluvelmente igualitárias e desiguais, aristocráticas e democráticas" (Manin, 1997, p. 149; ênfase suprimida). O polo democrático é o eleitorado; os eleitos são a faceta aristocrática. Esta ambiguidade é estruturante de várias das características da luta política nas democracias representativas contemporâneas. Os candidatos às posições de liderança precisam, a um só tempo, parecer idênticos a seus constituintes, cujos interesses, opiniões ou perspectivas desejam representar, e distintos deles, já que devem indicar que são capazes de desempenhar esta representação melhor do que quaisquer outros.

O discurso político deve se curvar diante de tais constrangimentos, esforçando-se por sinalizar identidade $e$ distinção, marcando o emissor como alguém que é gente-como-a-gente mas que, também, é mais capaz do que nós. Sendo um discurso permanentemente interessado, falta-lhe sempre a "autenticidade" que se espera nas relações interpessoais ${ }^{6}$. O que há de fake no discurso político, porém, não se resume àquilo que venho chamando de Kitsch, e que designa o componente de distinção. A impressão de identidade também é construída por meio de artifícios, que fazem com que políticos oriundos das elites ganhem roupagem popular ou se aproximem de setores da população estranhos à sua trajetória. A qualidade e intensidade do investimento, por sua vez, dependem das circunstâncias. Se Fernando Henrique Cardoso, em campanha eleitoral, subia num jegue e garantia ter um "pé na cozinha”, Luís Inácio Lula da Silva, partindo de uma posição oposta, aprimorava o vocabulário, incluindo construções menos usuais e termos técnicos extraídos da economia ou da geografia.

Cabe anotar, aqui, outra diferença que separa a democracia representativa que nós temos da democracia direta da Grécia antiga. A liderança

É claro que, a rigor, tal "autenticidade"sempre nos escapa, uma vez que construímos permanentemente nossas personas, nos diversos ambientes que freqüentamos: o processo de "representação do eu", como analisou Goffman (1959). 
política era um fator atuante na democracia ateniense, a tal ponto que identificamos períodos inteiros com os líderes de maior destaque (Sólon, Clístenes, Péricles). Não resta dúvida de que estes homens dispunham de competências especiais, tornando-se intérpretes da multidão e manejando-a a seu favor. No entanto, as diferenças deveriam ser apagadas, como demonstra não apenas a existência de uma instituição como o ostracismo, que privava dos direitos políticos aqueles que se destacassem em demasia, mas também o esforço retórico despendido para refutar a presença de qualquer qualidade distintiva - aí incluído o próprio domínio da retórica, ferramenta essencial da disputa política. Trata-se da demonstração do império de uma ideologia radicalmente igualitária, ou daquilo que um estudioso das elites políticas atenienses chamou de "hegemonia ideológica das massas" (Ober, 1989, p. 333).

A crença igualitária, que até Tocqueville era considerada constitutiva da democracia, foi debilitada com a ascensão do que Manin chama de "princípio da distinção" - o governo deve ser confiado aos melhores, em oposição ao "princípio da rotação", segundo o qual todos devem governar e ser governados alternadamente, vigente na democracia antiga. A busca da distinção está presente também no Kitsch estético, que representa, para seus consumidores, uma busca de elevação. De acordo com a definição de Umberto Eco citada anteriormente, o significativo não é que o Kitsch provoque em seus admiradores um gozo estético que é recusado por gostos mais refinados, mas que ele sugira (falsamente) que se trata de uma obra de arte legítima. O ponto não é gostar de estatuetas de biscuit, de Ray Conniff ou de Milan Kundera, mas de imaginar que se tratam de esculturas "verdadeiras", de música orquestral "de categoria" ou de "alta" literatura e que seriam capazes de promover a distinção social associada à sofisticação artística.

Da forma como coloca a questão em Apocalípticos e integrados, Umberto Eco permanece vinculado à crença na artisticidade intrínseca das obras superiores. É possível superar este limite aproximando a discussão sobre o Kitsch da análise que Pierre Bourdieu faz da relação entre distinção social e consumo cultural. Sob este prisma, o consumidor do Kitsch é incapaz de avaliar o valor de mercado simbólico dos diferentes produtos culturais. Trata-se, na verdade, de uma armadilha da qual não pode escapar: se consumisse as obras "certas", elas se desvalorizariam pelo simples fato de congregarem os consumidores "errados" (Bourdieu, 1979). 
Para a maior parte das pessoas, está vedada a possibilidade de uma expressão própria, significativa, quer no campo artístico, quer no campo político. Um discurso consolador quer nos fazer crer que todos fazemos política e também que todos fazemos arte, o que de certa forma pode ser verdade. Mas a política e a arte do cotidiano são quase sempre impotentes para ingressar nos respectivos campos sociais e, neles, fazerem diferença. A liberdade formal de expressão, elemento crucial do ordenamento jurídico das democracias representativas, não garante a possibilidade de enunciação de discursos políticos (ou artísticos) efetivos. Para tal, são necessários certos recursos materiais e, sobretudo, a posse de certas competências, socialmente adquiridas, que permitem a formulação de um discurso que será reconhecido como político ou artístico.

$\mathrm{Na}$ ausência de tais competências, o discurso perde legitimidade e não é reconhecido por aqueles que integram o campo. Assim, a expressão artística das classes subalternas é quase sempre desqualificada como depoimento ou então circunscrita ao artesanato ou ao folclore. Basta lembrar da recepção dada à literatura de Carolina Maria de Jesus, valorizada apenas por seu elemento testemunhal, ou que o interesse despertado pela obra de um Arthur Bispo do Rosário esteja sempre vinculado ao conhecimento de sua biografia, elemento que parece dispensável quando se trata de artistas plásticos como, digamos, Farnese de Andrade ou Nelson Leirner (para permanecer entre criadores que trabalham com assemblage $)^{7}$.

Na política, a voz popular tende a ser restrita à posição de ilustração de uma determinada posição, veiculando demandas ou posturas afetivas que o "verdadeiro" discurso político vai elaborar. Na qualidade de porta-voz, o representante é aquele que sabe expressar o que sua base deseja; e, como o discurso também constitui o mundo, ao expressá-las, ele também vai construindo as demandas que representa.

O Kitsch contribui para marcar a distância entre o discurso corrente, que é também o da mídia, o discurso que o cidadão comum poderia enunciar, e o discurso "elaborado" da política, produzindo um efeito legitimador. Ele pode ser entendido como parte do mecanismo de dominação que contribui para fechar o campo político à intrusão dos leigos. Como observa Bourdieu,

A permeabilidade da música popular a artistas das classes subalternas é evidência de seu baixo prestígio, nos termos de Bourdieu (1979). A música erudita, por sua vez, apresenta a situação oposta. 
a linguagem dominante [no campo político] destrói, ao desacreditá-lo, o discurso político espontâneo dos dominados: não lhes deixa outra opção que não o silêncio ou a linguagem emprestada, cuja lógica não é mais a do uso popular, sem ser a do uso culto, linguagem enguiçada, onde as "palavras elevadas" estão presentes apenas para assinalar a dignidade da intenção expressiva e que, nada podendo transmitir de verdadeiro, de real, de "sentido", priva aquele que a fala da experiência mesma que julga exprimir. (Bourdieu, 1979, p. 538)

A exigência de adequação ao padrão considerado correto de discurso político é, assim, um dos principais mecanismos pelos quais o campo político exclui os que não devem participar dele e adequa seu formato formalmente democrático ao modo oligárquico com que funciona.

A compreensão da política como um campo estruturado, capaz de excluir, de cobrar adequações, de impor constrangimentos, permite romper com o normativismo ingênuo que prescreve as regras de uma boa política voltada ao entendimento mútuo. O ideal da chamada democracia deliberativa, inspirado na ação comunicativa habermasiana, mostra-se infrutífero para enfrentar os problemas da democracia contemporânea por pressupor que a capacidade de emitir discursos políticos é igualmente compartilhada por todos ${ }^{8}$.

O campo político possui materialidade - no mesmo sentido em que Althusser afirmava que a ideologia tem existência material, isto é, produz as práticas humanas. Os excluídos da política tendem a excluir a si mesmos, introjetando o sentimento de incompetência e conformando-se em calar ou ser falados por outrem. Quando, a despeito disso, falam, sua fala tende a ser negligenciada, pois carece dos signos de legitimidade para que seja ouvida. Uma fala, ademais, frequentemente insegura, pois ciente de seu caráter transgressor. Em situações assim, como observa Bourdieu, não são raros o enrubescimento, a gagueira, o tremor: "maneira de vivenciar, por vezes com conflito interior e clivagem do eu, a cumplicidade subterrânea que um corpo, que se subtrai às diretivas da consciência e da vontade, mantém com as censuras inerentes às estruturas sociais" (Bourdieu, 1998b, p. 45). Os signos de inadequação - e de ilegitimidade - se tornam, assim, ainda mais patentes.

Mais do que buscar o espaço utópico da "discussão livre e desinteressada entre iguais", como fazem os democratas deliberativos, o aprimoramento da

Para uma crítica aprofundada, ver Miguel (2002b). 
democracia - sua aproximação com o ideal que a palavra carrega - exige a transformação do campo político, dando instrumentos para que os grupos subalternos ingressem nele. Até lá, o discurso político permanecerá como uma ferramenta de exclusão; e o Kitsch político é um índice desta postura exclusionária.

\section{Conclusões}

O paralelo aqui feito entre a expressão artística e a política não deve obscurecer as diferenças que as separam - e que afetam a posição do Kitsch em cada uma delas. A produção artística é marcada pela busca da voz individual, da originalidade, bem como pela recusa do que é "fácil". Nela, a popularidade costuma se tornar um estigma; o verdadeiro artista, afinal, deve estar à frente de seu tempo, deve assustar o bom gosto burguês, deve vencer os preconceitos. Apropriação de repertórios já consagrados, simplificados e pasteurizados para o consumo das massas, o Kitsch é uma contrafação que só engana os completamente despossuídos de competência para julgar.

Na política, porém, a popularidade é essencial. O capital político, como qualquer forma de capital simbólico, é conferido pelos integrantes do próprio campo: trata-se do reconhecimento pelos pares. Sobretudo - mas não só em regimes de concorrência eleitoral, como os que vigoram no Ocidente, uma parte deste reconhecimento é devida à capacidade de obter o apoio dos profanos, isto é, daqueles que estão à margem do campo político. Não se trata de uma relação mecânica; um campeão eventual de votos (Agnaldo Timóteo em 1982, Celso Russomano em 1994, Enéas Carneiro em 2002, Tiririca em 2010, para citar apenas alguns exemplos) pode permanecer na posição de figura política mais do que secundária. Mas, como regra geral, a ampliação da capacidade de angariar apoio popular contribui para aumentar, não para diminuir, o capital político.

A relação entre distinção e identificação é, portanto, muito mais complexa no caso da política. Por isso, por se manter acessível ao mesmo tempo em que promove a valorização simbólica de quem o emite, o Kitsch é uma das formas-padrão do repertório do discurso político, quando dirigido aos cidadãos comuns, nas democracias representativas contemporâneas.

$\mathrm{Na}$ arte, a fronteira entre a expressão legítima e o Kitsch é posta em questão por artistas reconhecidos - por museus, por críticos, por curadores - que absorvem a estética Kitsch e oferecem a ela a guarida de sua própria 
autoridade simbólica. O nome mais célebre é o de Jeff Koons, com seus cachorros floridos gigantes, seus coelhinhos de plástico metalizado, suas pinturas de folhinha de mercearia ou mesmo a controversa parceria com sua ex-mulher, a estrela do cinema pornô Cicciolina, de quem exibiu fotografias com conteúdo sexual explícito ${ }^{9}$. A rigor, trata-se da atualização de uma velha estratégia de desconstrução dos critérios de valoração artística, iniciada nos primeiros anos do século XX pelos ready-mades de Marcel Duchamp. No campo político, porém, não há espaço para vanguardas. O Kitsch cumpre seu propósito de alavancar o apoio das bases; não esconde um discurso "autêntico" ou "elevado" por trás dele, já que tal discurso não existe.

O que a discussão sobre o Kitsch expõe é a ambiguidade do estatuto atual da política, que se mantém como atividade para poucos, embora se democratize; e que se mantém como atividade elevada, séria, embora seus atores estejam competindo pela atenção pública num ambiente dominado pelo entretenimento. É necessário se adequar ao discurso corrente da mídia, para não alienar o público, mas ao mesmo tempo preservar suas marcas de distinção. Da mesma forma como a competição política exige a utilização de técnicas publicitárias, estas, uma vez expostas em excesso, se tornam problemáticas. Estigmatizado como produto de marketing, o político fica vulnerável à acusação de não ter personalidade, nem projeto, enfim, de não possuir as qualidades especificamente políticas que deveriam credenciá-lo.

\footnotetext{
Cicciolina, não custa lembrar, representou um símbolo da "degradação" da política ao se eleger para o parlamento italiano em 1988. Ao contrário da interpretação convencional que circulava na época, sua eleição não representou um sintoma de crise por ela ser "pouco séria" ou por ter realizado uma campanha em que a única plataforma apresentada eram os seios da candidata. Pessoas ainda menos sérias, com programas políticos ainda menos consistentes, frequentam os parlamentos "desde sempre". O novo, na campanha e na vitória eleitoral de Cicciolina, é a forma de articulação entre a política institucional, o campo político e a esfera pública. São numerosos os casos em que a notoriedade obtida em espaços variados da esfera pública é convertida em votos, possibilitando que pessoas públicas não-detentoras de capital especificamente político (artistas, esportistas, religiosos) concorram e sejam eleitas para o parlamento e, menos frequentemente, para o executivo. Eventualmente, o novo parlamentar se desvincula da popularidade obtida em sua área de atuação original e passa a acumular capital político. Torna-se um integrante de pleno direito do campo político, não mais um forasteiro. Em todos esses casos, há uma direção bem definida: de um foco produtor de popularidade inicial para o parlamento (política institucional), e daí, quando possível, para o campo político. No caso de Cicciolina, essa direção é subvertida. O campo político deixa de ter importância; o parlamento não é mais um objetivo relevante. Torna-se apenas um elemento de uma estratégia publicitária, voltada afinal para sua própria origem, o mercado de produtos pornográficos. Ao contrário dos outros, Cicciolina não usou sua popularidade para ingressar no parlamento. Usou a campanha eleitoral e o próprio parlamento para ampliar sua popularidade. Relegando o parlamento a uma peça de marketing, a pornstar italiana dramatizou a crise da política institucional nas sociedades contemporâneas.
} 
O político é alguém que participa do mundo da mídia, mas deve manter a dignidade e não se curvar a todas as suas imposições. Para quem julga a política de hoje pelos padrões de um passado mítico, pode parecer chocante que candidatos à presidência sejam entrevistados em programas humorísticos, que um presidente eleito tenha atuado como comentarista de um telejornal, que senadores participem da gravação de uma telenovela ou que a presidente da República prepare omeletes num programa "feminino"10. Mas candidatos à presidência não são humoristas (ao menos não voluntariamente), presidentes não são apresentadores de televisão, senadores não são artistas de novela. O público não os confunde; e, mesmo nestes ambientes, o discurso político permanece distinto.

Em outras palavras: é possível focar nossa atenção no fato de que o então vice-presidente dos Estados Unidos, Al Gore, foi convidado a empinar uma vassoura sobre o nariz num programa de variedades da televisão (Gabler, 1999 [1998], p. 114). Mas convém não esquecer de que Gore se recusou a fazê-lo; e de que a proposta nos parece tão ousada exatamente por aviltar a aura de dignidade que, bem ou mal, a política ainda é capaz de carregar.

O discurso político precisa se adaptar ao novo ambiente gerado pelos meios de comunicação de massa, bem como a prática política incorpora os recursos que lhe são fornecidos pelas técnicas publicitárias e pelo marketing. Mas é uma apropriação seletiva, que pressupõe uma negociação tácita entre a mídia, que detém os instrumentos de produção da visibilidade social, e o político, que conhece ou intui os limites para além dos quais sua exposição pública se torna contraproducente.

\section{Referências bibliográficas}

ALTHUSIUS, Johannes. 2003 [1614]. Política. Edição de Frederick S. Carney. Rio de Janeiro: Topbooks.

BOURDIEU, Pierre. 1979. La distinction: critique sociale du jugement. Paris: Minuit. . 1998a [1982]. A economia das trocas lingüísticas. São Paulo: Edusp. . 1998b. La domination masculine. Paris: Seuil.

ECO, Umberto. 1988a [1962]. Obra aberta. São Paulo: Perspectiva.

\footnotetext{
- Não custa lembrar que, no passado, os líderes políticos também procuravam aparecer de forma mais informal diante de seu público - por exemplo, frequentando os salões da"sociedade". O desenvolvimento da comunicação de massa ocorre em paralelo com a ampliação do público relevante para o político.
} 
. 1988b [1967]. "Introdução à segunda edição". Obra aberta. São Paulo: Perspectiva.

. 1993 [1964]. Apocalittici e integrati: comunicazioni di massa e teorie della cultura di massa. Milano: Bompiani.

FINLEY, Moses I. 1988 [1973]. Democracia: antiga e moderna. Rio de Janeiro: Graal.

GABLER, Neal. 1999 [1998]. Vida, o filme: como o entretenimento conquistou a realidade. São Paulo: Companhia das Letras.

GOFFMAN, Erving. 1959. The presentation of self in everyday life. Garden City: Doubleday.

GOMES, Wilson. 2004. Transformações da política na era da comunicação de massa. São Paulo: Paulus.

GORZ, André. 1988. Métamorphoses du travail: quête du sens: critique de la raison économique. Paris: Galilée.

HABERMAS, Jürgen. 1980 [1976]. "O conceito de poder de Hannah Arendt”. Habermas: sociologia. São Paulo: Ática.

HOBBES, Thomas. 1980 [1651]. Leviatán. Ciudad de México: Fondo de Cultura Económica.

KUNDERA, Milan. 1984 [1983]. L'insoutenable légèreté de l'être. Paris: Gallimard.

LASCH, Christopher. 1995 [1995]. A rebelião das elites e a traição da democracia. Rio de Janeiro: Ediouro.

LOSURDO, Domenico. 2004 [1993]. Democracia ou bonapartismo: triunfo e decadência do sufrágio universal. Rio de Janeiro/São Paulo: Editora UFRJ/Editora Unesp.

MANIN, Bernard. 1997. The principles of representative government. Cambridge: Cambridge University Press.

MIGUEL, Luis Felipe. 2002a. "Os meios de comunicação e a prática política”. Lua Nova, n. 55-56, p. 155-184.

.2002b. "As duas lógicas da ação comunicativa: democracia e deliberação no debate contemporâneo". Teoria \& Sociedade, n. 10, p. 104-143. OBER, Josiah. 1989. Mass and elite in democratic Athens: rethoric, ideology, and the power of the people. Princeton: Princeton University Press.

PLOT, Martín. 2003. El Kitsch político. Buenos Aires: Prometeo.

THOMPSON, Edward P. 1987 [1963]. A formação da classe operária inglesa, 3 v. São Paulo: Paz e Terra. 


\title{
Resumo
}

Segundo Umberto Eco, uma das características do Kitsch é se constituir em "meio de afirmação cultural fácil, por um público que se ilude, julgando consumir uma representação original do mundo enquanto, na verdade, goza apenas de uma imitação secundária da força primária das imagens". O artigo desenvolve um entendimento de Kitsch político, observando que, na era dos meios eletrônicos de comunicação, o discurso político deve utilizar signos de distinção, que marquem suas diferenças em relação às formas expressivas correntes na mídia e deem à audiência a impressão de assistir à "alta política", associada à "disputa de ideias" e à discussão aprofundada.

Palavras-chave: Kitsch; discurso político; representação política; mídia e política; estética política.

\begin{abstract}
According to Umberto Eco, a characteristic of Kitsch is to constitute "an easy means of cultural affirmation for a public who deceives itself, believing it consumes an original representation of the world while, in truth, it only enjoys a secondary mimic of the primary force of images." This paper develops an understanding of the political Kitsch, pointing that, in the era of electronic media, political discourse must use distinction signs that mark its differences relative to current expressive forms in the media and giving the audience the impression of seeing "high politics", associated to the "debate of ideas" and deep discussion.
\end{abstract} Key words: Kitsch; political discourse; political representation; media and politics; political aesthetics. 